\title{
IMPACT OF AN URBAN SANITATION INTERVENTION ON ENTERIC PATHOGEN DETECTION IN SOILS
}

Authors: Drew Capone ${ }^{1}$, David Berendes ${ }^{2}$, Oliver Cumming ${ }^{3}$, David Holcomb ${ }^{4}$, Jackie Knee ${ }^{3}$, Konstantinos T. Konstantinidis ${ }^{5}$, Karen Levy ${ }^{6}$, Rassul Nalá ${ }^{7}$, Benjamin B. Risk ${ }^{8}$, Jill Stewart ${ }^{1}$, Joe Brown ${ }^{1 *}$

1. Department of Environmental Sciences and Engineering, Gillings School of Public Health, University of North Carolina at Chapel Hill, Chapel Hill, North Carolina, United States of America

2. Waterborne Disease Prevention Branch, Division of Foodborne, Waterborne, and Environmental Diseases, National Center for Emerging Zoonotic and Infectious Diseases, Centers for Disease Control and Prevention, Atlanta, Georgia, United States of America

3. Department of Disease Control, London School of Hygiene and Tropical Medicine, London, United Kingdom

4. Department of Epidemiology, Gillings School of Global Public Health, University of North Carolina at Chapel Hill, Chapel Hill, North Carolina, United States of America

5. Civil and Environmental Engineering, Georgia Institute of Technology, 311 Ferst Drive, Atlanta, Georgia, United States of America

6. Environmental and Occupational Health Sciences, University of Washington, 298015 th Ave NE, Seattle, Washington, United States of America

7. Ministério da Saúde, Instituto Nacional de Saúde Maputo, Maputo, Mozambique

8. Department of Biostatistics and Bioinformatics, Emory University, Atlanta, Georgia, United States of America

*Corresponding author: Joe Brown

Phone: +1 919-360-8752

Email: joebrown@unc.edu

Address: 135 Dauer Dr, Chapel Hill, NC 27599, USA 


\section{ABSTRACT}

Environmental fecal contamination is common in many low-income cities, contributing to a high burden of enteric infections and associated negative sequelae. To evaluate the impact of a shared onsite sanitation intervention in Maputo, Mozambique on enteric pathogens in the domestic environment, we collected 179 soil samples at shared latrine entrances from intervention $(n=49)$ and control $(n=51)$ compounds during baseline (pre-intervention) and after 24 months (postintervention) as part of the Maputo Sanitation Trial. We tested soils for the presence of nucleic acids associated with 20 enteric pathogens using a multiplex reverse transcription qPCR platform. We detected at least one pathogen-associated target in 91\% (163/179) of soils and a median of $3(\mathrm{IQR}=1.5,5)$ pathogens. Using a difference-in-difference analysis and adjusting for compound population, visibly wet soil, sun exposure, wealth, temperature, animal presence, and visible feces, we estimate the intervention reduced the probability of $\geq 1$ pathogen detected by $15 \%$ (adjusted prevalence ratio, aPR $=0.85 ; 95 \% \mathrm{CI}: 0.70,1.0)$ and the total number of pathogens detected by $35 \%(\mathrm{aPR}=0.65 ; 0.44,0.95)$ in soil 24 months following the intervention. These results suggest that the intervention reduced the presence of some fecal contamination in the domestic environment, but pathogen detection remained prevalent 24-months following the introduction of new latrines. 


\section{INTRODUCTION}

Onsite sanitation systems are designed to sequester human feces away from human contact and prevent the transport of fecal-oral pathogens through well-understood transmission pathways. ${ }^{1}$

Large-scale, rigorous randomized controlled trials (RCTs) of onsite sanitation systems including sanitation alone and combinations of water, sanitation, and hygiene (WASH) interventions - have found mixed effects on health outcomes, such as diarrhea and child growth. ${ }^{2-7}$ Assessing the impact of WASH interventions on enteric pathogens in the environment can improve our understanding of pathogen transmission from an infected individual to a new host via the environment, a core intermediate outcome of these trials. Such data may help explain why some WASH interventions observed improved health outcomes and others did not. ${ }^{8}$

There is a growing body of literature that soils contaminated by feces in public and domestic environments pose infection risks. ${ }^{9-13}$ In health impact trials that assess improved onsite sanitation systems, soils are assessed to measure how effectively the intervention sequestered human feces. ${ }^{14-18}$ Latrines and septic tanks are useful barriers against the transport of human feces into the environment. However, enteric pathogens may still move into soils through open defecation ${ }^{19}$, unhygienic pit emptying ${ }^{20,21}$, fecally contaminated greywater ${ }^{22,23}$, improper disposal of children's feces or anal cleansing materials ${ }^{24,25}$, latrine flooding ${ }^{20,26,27}$, animal feces ${ }^{28-30}$, or subsurface transport from unlined pits ${ }^{31-33}$. Domestic soils contaminated by enteric pathogens can pose infection risks beyond incidental ${ }^{34}$ and $\operatorname{direct}^{35}$ soil ingestion: contaminated soil may be transported to hands, food, fomites, or household stored water. ${ }^{36}$ For these reasons, soils may be a useful matrix to assess the impact of onsite sanitation interventions. 
Detecting enteric pathogens via molecular methods is increasingly used to assess the impact of WASH interventions on the transport of these pathogens through the environment. ${ }^{37-39}$ Molecular detection of pathogens offers additional insights, as health impact studies have historically relied on fecal indicator bacteria (FIB), as a proxy for enteric pathogens for reasons of cost, capacity and feasibility. ${ }^{17,36,40-42}$ However, a 2016 meta-analysis ${ }^{43}$ found that improved sanitation had no effect on the presence of FIB in the environment, possibly because these indicators are often pervasive in low-income settings ${ }^{15,16,36,44-46}$ and common FIB, like E. coli, may be naturalized in the environment ${ }^{47-49}$.

The Maputo Sanitation (MapSan) Trial was the first rigorous controlled before-and-after trial to evaluate the effect of an urban onsite sanitation intervention on child health. ${ }^{24,50,51} \mathrm{We}$ conducted the trial in low-income, informal neighborhoods in Maputo, Mozambique, where WASH conditions are poor, and the burden of enteric disease is high. ${ }^{20,24,44,52}$ Water and Sanitation for the Urban Poor (WSUP, a non-governmental organization) delivered the intervention to compounds composed of household clusters that shared sanitation and courtyard space. The intervention was built inside the compound boundary and was part of the households' living environment. WSUP replaced shared onsite sanitation systems in poor condition with pour-flush toilets that included septic tanks and soak-away pits (Text S1). Control compounds were concurrently enrolled from the same or adjacent neighborhoods as intervention compounds and continued using existing shared sanitation infrastructure. Detailed descriptions of the inclusion criteria for intervention and control compounds are described elsewhere..$^{20,24}$

A latrine entrance is an ideal soil sampling location to determine the effectiveness of onsite sanitation interventions because it is a standardized location near the fecal waste in the containment chamber. ${ }^{15,16,53}$ Soils in low-income Maputo are characterized as coarse to fine sand 
or silty sand. ${ }^{54}$ While the fate and transport of pathogens through soils is dependent on the individual pathogen and environmental conditions ${ }^{55}$, the high porosity of Maputo’s sandy soils combined with a high water table in the study area ${ }^{44}$ offers potential for pathogen movement. ${ }^{56}$ This high risk of fecal contamination suggests we could plausibly observe a reduction in enteric pathogens in soil at latrine entrances if the intervention infrastructure performed better than controls at safely containing fecal wastes. ${ }^{57}$ Our study aim was to assess if the intervention reduced the detection of $\geq 1$ pathogen, the total number of pathogens, or any individual pathogen in latrine entrance soils from MapSan intervention compounds compared to controls.

\section{MATERIALS AND METHODS}

\section{Sample Collection}

We prospectively collected latrine entrance soil samples - defined as a location one-meter away from the latrine entrance in the direction of entry or the nearest point not covered by cement from 49 intervention and 51 control compounds at baseline (pre-intervention) and from the same compounds 24-months following the intervention, for a total of 200 samples (Text S2). We defined this sample location a priori as one that could be standardized across all compounds in the study. Using a spade and ruler, we scooped a $10 \mathrm{~cm}$ x $10 \mathrm{~cm}$ x $1 \mathrm{~cm}$ volume of soil into a Whirl-Pak $^{\circledR}$ bag (Nasco, Fort Atkinson, WI). The spade and ruler were sterilized between uses with $10 \%$ bleach and $70 \%$ ethanol. At the time of sampling, enumerators recorded whether the soil was visibly wet and estimated the daily sun exposure (full sun, partially shaded, full shade). ${ }^{44}$ Samples were stored on ice for transport to the Ministry of Health in Maputo, Mozambique, frozen at $-20^{\circ} \mathrm{C}$ for approximately six months, aliquoted into $2 \mathrm{ml}$ cryovials while working on dry ice, and then stored at $-80^{\circ} \mathrm{C}$. During storage at $-20^{\circ} \mathrm{C}$, some samples $(\mathrm{n}=21)$ 
were unable to be evaluated because the permanent marker labeling on some Whirl-Pak ${ }^{\circledR}$ bags wore off and some bags burst open. All aliquoted samples $(n=179)$ were shipped from the Mozambican Ministry of Health in Maputo, Mozambique to Atlanta, GA, USA on dry ice (-80 C) with temperature monitoring for molecular analysis. We obtained compound observation data and socioeconomic characteristics from the MapSan baseline and 24-month survey datasets, which were collected concurrent to soil samples. ${ }^{24,58}$

\section{Sample Processing}

At Georgia Institute of Technology in Atlanta, GA, USA, we incubated $250 \mathrm{mg}$ of each soil sample at $105^{\circ} \mathrm{C}$ for 1 hour to determine moisture content ${ }^{13,59}$, then discarded the dry soil. We then extracted total nucleic acids from a separate 1-gram (calculated for dry weight) portion of each sample, and spiked samples with MS2 (Luminex Corporation, Austin, TX) as an extraction control. Following the manufacturer's protocol, we extracted RNA using the RNeasy PowerSoil Total RNA Kit and DNA using the RNeasy PowerSoil DNA Elution Kit (Qiagen, Hilden, Germany). On each day of extraction (approximately every 5-15 samples), we included one negative extraction control (sterile deionized water). We tested sample extracts for matrix inhibition using the Applied Biosystems Exogenous Internal Positive Control Assay ${ }^{60}$ (Applied Biosystems, Waltham, Massachusetts) before downstream molecular analysis (Text S3).

We assayed extracted nucleic acids from all samples using a custom TaqMan Array Card (TAC) (ThermoFisher Scientific, Waltham, MA) that tested for 20 enteric pathogens in duplicate wells following Liu et al. $2013^{61}$, including ten bacteria (Campylobacter jejuni/coli, Clostridium difficile [tcdA and $t c d B$ gene], Enteroaggregative E. coli [EAEC, aaiC and aatA gene], Shigella/Enteroinvasive E. coli [EIEC, ipaH gene], Enteropathogenic E. coli [EPEC, bfpA and 
eae gene], Enterotoxigenic E. coli [ETEC, heat-labile and heat-stabile enterotoxin gene], Shigatoxin producing E. coli [STEC, stx1 and stx2], Salmonella spp., Vibrio cholerae, and Yersinia spp.), five viruses (adenovirus 40/41, astrovirus, norovirus [GI and GII], rotavirus A, and sapovirus [I, II, IV, and V],), three protozoa (Cryptosporidium parvum, Entamoeba histolytica, and Giardia duodenalis) and two soil-transmitted helminths (Ascaris lumbricoides, Trichuris trichiura) (Text S4, Table S1, Table S2). ${ }^{62}$ We combined and then added $25 \mu \mathrm{L}$ of RNA eluant, $25 \mu \mathrm{L}$ of DNA eluant, and $50 \mu \mathrm{L}$ of mastermix into each TAC port. We included a positive and negative control on each TAC. The positive control was a plasmid that included all assay gene sequences and the negative control was either extract from a negative extraction control or sterile water. ${ }^{63}$ The thermocycling conditions were as follows: $45^{\circ} \mathrm{C}$ for 10 minutes and $94^{\circ} \mathrm{C}$ for 10 minutes, followed by 45 cycles of $94^{\circ} \mathrm{C}$ for 30 seconds and $60^{\circ} \mathrm{C}$ for 1 minute, with a ramp rate of $1{ }^{\circ} \mathrm{C} /$ second between each step. We visually compared exponential curves and multicomponent plots with the positive control plots to validate positive amplification ${ }^{12}$; positive amplification in one or both duplicate wells below a quantification cycle $(\mathrm{Cq})$ of 40 was called as a positive for a target (Text S4). ${ }^{62,64}$

\section{Data analysis}

We analyzed data in $\mathrm{R}$ version 4.0.0 (R Foundation for Statistical Computing, Vienna, Austria). We used a difference-in-difference (DID) ${ }^{65}$ approach to assess the impact of the intervention our exposure variable - on our outcomes compared to the control group. Our outcomes included the detection (i.e., binary presence/absence) of $\geq 1$ of the enteric pathogens measured, the total number of pathogens detected out of 20 , and a separate analysis for each pathogen individually. We used generalized estimating equations $(\mathrm{GEE})^{66}$ to fit unadjusted and adjusted Poisson regression models with robust standard errors, with an exchangeable correlation structure. We 
accounted for clustering between compounds across the two study phases because the intervention was implemented at the compound level. ${ }^{67}$

To generate adjusted estimates, we selected nine covariates from the MapSan baseline and 24month datasets based on their biological plausibility to impact the transport ${ }^{57}$ or persistence ${ }^{68}$ of pathogens in the domestic environment and previously reported associations in the literature 36,44 (Table S3). We used the same nine covariates to adjust all DID models: compound population (a 10-person increase in compound population), wealth (one-quartile increase in wealth index ${ }^{69}$ ), soil moisture (assessed visually at the time of sampling), sun exposure status (estimated at the time of sampling; full sun, partially shaded, shaded ${ }^{44}$ ), the mean-centered average air temperature in Fahrenheit for the day of and day preceding sample collection (i.e., two-day average), a binary variable for the presence of cats, a binary variable for the presence of dogs, a binary variable for the presence of chickens or ducks, and a binary variable for the presence of visible animal or human feces in the compound (Table S4).

To estimate the intervention's effect, we used the interaction of dummy variables representing treatment status (intervention vs. control) and trial phase (baseline or 24-month). Consequently, we present the effect estimates from our DID analysis as ratio measures (ratio of prevalence ratios, PR) instead of absolute differences. We fit separate GEE models to measure the association between intervention status and the detection of $\geq 1$ pathogen and the total number of pathogens detected among the 20 targets we identified a priori. Likewise, we fit DID models to estimate the intervention's impact for each individual pathogen assessed, but we excluded any pathogen not detected in at least $5 \%$ of control and intervention samples during both phases.

\section{Ethics}


The study protocol was approved by the Comité Nacional de Bioética para a Saúde (CNBS), Ministério da Saúde (333/CNBS/14), the Research Ethics Committee of the London School of Hygiene and Tropical Medicine (reference \# 8345), and the Institutional Review Board of the Georgia Institute of Technology (protocol \# H15160). The overall trial was pre-registered at ClinicalTrials.gov (NCT02362932), but we did not pre-register this environmental analysis.

\section{RESULTS (723 words)}

\section{Matched samples}

We analyzed latrine entrance soils collected at baseline from 48 control compounds and 43 intervention compounds, and soils collected at the 24-month phase from 45 control and 43 intervention compounds (Table S4). We did not analyze twelve intervention samples and nine control samples because they were either lost or damaged during storage. This resulted in some samples collected at either phase not having a matched sample from the same compound from the earlier or later phase. Among the 93 control samples analyzed, 42 compounds had samples from both phases $(n=84)$, six baseline samples did not have a matched 24-month phase sample, and three 24-month samples did not have a matched baseline sample. Among the 86 intervention samples analyzed, 41 compounds had samples from both phases $(n=82)$, two baseline samples did not have a matched 24-month phase sample, and two 24-month samples did not have a matched baseline sample. There was a mean of 788 days between the collection of matched control samples $(\mathrm{sd}=36, \min =733, \max =860)$ and a mean of 789 days between matched intervention samples $(\mathrm{sd}=56, \min =731, \max =953)$. Control and intervention samples were collected approximately during the same period of the year (Figure S1).

\section{Compound characteristics}


Control and intervention compounds had similar wealth indices at baseline (mean $=0.47$ $[\mathrm{sd}=0.09]$ and mean $=0.46[\mathrm{sd}=0.09]$, respectively, $\mathrm{p}=0.49)$ but control compounds had higher wealth indices at the 24-month phase (mean $=0.46[\mathrm{sd}=0.12]$ and mean $=0.40[\mathrm{sd}=0.09]$, respectively, $\mathrm{p}=0.05$ ) (Table 1). The number of residents in the intervention compounds was greater than control compounds at baseline (mean $=19[\mathrm{sd}=7.8]$ and mean $=14[\mathrm{sd}=6.4]$, respectively, $\mathrm{p}=0.004)$ and at the 24 -month phase (mean=16 [sd=7.9] and mean=13 [sd=7.0], respectively, $\mathrm{p}=0.02)$ (Table 1$)$.

Reported or observed animal ownership was high across trial arms during both phases (Table 1). Most compounds had at least one animal at baseline (62\% [56/91]) including cats (50\% [24/48] control, 53\% [23/43] intervention), chickens or ducks (13\% [6/48] control, 16\% [7/43] intervention), and dogs (6.3\% [3/48] control, 9.3\% [4/43] intervention). Three-quarters of compounds had at least one animal 24-months post intervention (76\% [67/88]): cats were most common (71\% [32/45] control, 70\% intervention [30/43]), followed by dogs (20\% [9/45] control, 23\% [10/43] intervention), and chickens or ducks (8.9\% [4/45] control, 19\% [8/43] intervention).

At baseline seven compounds had no useable sanitation infrastructure (6.3\% [3/48] control, 9.3\% [4/43] intervention) and three compounds had pour-flush sanitation (4.2\% [2/48] control, $2.3 \%$ [1/43] intervention) (Table 1). Control compounds more often had pit latrines with slabs (56\%, [27/48]) than without slabs $(33 \%,[16 / 48])$, compared to intervention compounds, which more often had pit latrines without slabs $(56 \%,[24 / 43])$ than with slabs $(33 \%,[14 / 43])(p=0.09)$. At the 24-month phase, most control compounds had a pit latrine (with slab 40\%, [18/45]; without slab $31 \%,[14 / 45])$, but some $(29 \%,[13 / 45])$ had independently upgraded their pit latrines to 
bioRxiv preprint doi: https://doi.org/10.1101/2021.04.02.438233; this version posted April 2, 2021. The copyright holder for this preprint (which was not certified by peer review) is the author/funder, who has granted bioRxiv a license to display the preprint in perpetuity. It is made available under aCC-BY-NC-ND 4.0 International license.

11

pour-flush toilets. All intervention compounds (100\%, [43/43]) still had the intervention sanitation infrastructure at the 24-month phase. 
1 Table 1. Characteristics of MapSan trial compounds and households selected for soil sampling

\begin{tabular}{|c|c|c|c|c|c|c|c|c|c|c|}
\hline \multirow{3}{*}{ Characteristic } & \multirow[b]{3}{*}{ Level } & \multirow[b]{3}{*}{ Metric } & \multicolumn{4}{|c|}{ Baseline } & \multicolumn{4}{|c|}{ 24-Month Phase } \\
\hline & & & \multicolumn{2}{|c|}{ Control } & \multicolumn{2}{|c|}{ Intervention } & \multicolumn{2}{|c|}{ Control } & \multicolumn{2}{|c|}{ Intervention } \\
\hline & & & $\mathbf{N}$ & Summary & $\mathbf{N}$ & Summary & $\mathbf{N}$ & Summary & $\mathbf{N}$ & Summary \\
\hline Wealth index (0-1) & household & mean $(\mathrm{sd})$ & 48 & $0.47(0.09)$ & 43 & $0.46(0.09)$ & 45 & $0.44(0.12)$ & 43 & $0.40(0.09)$ \\
\hline Compound population & compound & mean $(\mathrm{sd})$ & 48 & $14(6.4)$ & 43 & $19(7.8)$ & 45 & $13(7.0)$ & 43 & $16(7.9)$ \\
\hline Any animal(s) present & compound & $\mathrm{n}(\%)$ & 48 & $28(58 \%)$ & 43 & $28(65 \%)$ & 45 & $32(71 \%)$ & 43 & $35(81 \%)$ \\
\hline Cat(s) present & compound & $\mathrm{n}(\%)$ & 48 & $24(50 \%)$ & 43 & $23(53 \%)$ & 45 & $32(71 \%)$ & 43 & $30(70 \%)$ \\
\hline Chicken(s) or $\operatorname{duck}(\mathrm{s})$ present & compound & $\mathrm{n}(\%)$ & 48 & $6(13 \%)$ & 43 & $7(16 \%)$ & 45 & $4(8.9 \%)$ & 43 & $8(19 \%)$ \\
\hline $\operatorname{Dog}(\mathrm{s})$ present & compound & $\mathrm{n}(\%)$ & 48 & $3(6.3 \%)$ & 43 & $4(9.3 \%)$ & 45 & $9(20 \%)$ & 43 & $10(23 \%)$ \\
\hline Other animal(s) present & compound & $\mathrm{n}(\%)$ & 48 & $1(2.1 \%)$ & 43 & $2(4.7 \%)$ & 45 & $1(2.2 \%)$ & 43 & $0(0 \%)$ \\
\hline Visible feces & compound & $\mathrm{n}(\%)$ & 48 & $22(46 \%)$ & 43 & $22(51 \%)$ & 45 & $4(8.9 \%)$ & 43 & $4(9.3 \%)$ \\
\hline Visibly wet soil & sample & $\mathrm{n}(\%)$ & 48 & $37(77 \%)$ & 43 & $34(79 \%)$ & 45 & $37(82 \%)$ & 43 & $34(79 \%)$ \\
\hline Partially shaded soil & sample & $\mathrm{n}(\%)$ & 48 & $24(50 \%)$ & 43 & $13(30 \%)$ & 45 & $30(67 \%)$ & 43 & $28(65 \%)$ \\
\hline Fully shaded soil & sample & $\mathrm{n}(\%)$ & 48 & $14(29 \%)$ & 43 & $20(47 \%)$ & 45 & $10(22 \%)$ & 43 & $9(21 \%)$ \\
\hline Temperature $(\mathrm{F})$ & date & mean $(\mathrm{sd})$ & 48 & $72(4.5)$ & 43 & $70(4.3)$ & 45 & $72(4.7)$ & 43 & $73(5.3)$ \\
\hline $\begin{array}{l}\text { No useable sanitation } \\
\text { infrastructure }\end{array}$ & compound & $\mathrm{n}(\%)$ & 48 & $3(6.3 \%)$ & 43 & $4(9.3 \%)$ & 45 & $0(0 \%)$ & 43 & $0(0 \%)$ \\
\hline Pit latrine with slab & compound & $\mathrm{n}(\%)$ & 48 & $27(56 \%)$ & 43 & $14(14 \%)$ & 45 & $18(40 \%)$ & 43 & $0(0 \%)$ \\
\hline Pit latrine without slab & compound & $\mathrm{n}(\%)$ & 48 & $16(33 \%)$ & 43 & $24(56 \%)$ & 45 & $14(31 \%)$ & 43 & $0(0 \%)$ \\
\hline $\begin{array}{l}\text { Pour-flush toilet (non- } \\
\text { intervention) }\end{array}$ & compound & $\mathrm{n}(\%)$ & 48 & $2(4.2 \%)$ & 43 & $1(2.2 \%)$ & 45 & $13(29 \%)$ & 43 & $0(0 \%)$ \\
\hline Intervention infrastructure & compound & $\mathrm{n}(\%)$ & 48 & $0(0 \%)$ & 43 & $0(0 \%)$ & 45 & $0(0 \%)$ & 43 & $43(100 \%)$ \\
\hline
\end{tabular}

2 Note: Wealth index created using the 2013 Simple Poverty Scorecard@ $\odot$ for Mozambique 
13

4 We did not observe inhibition in any sample (Text S3). We observed positive amplification for

5 all assays using our positive controls $(n=32)$. We did not observe positive amplification for any

6 assay in our extraction controls $(n=16)$, nor any template controls $(n=16)$ below a Cq of 40 .

\section{$7 \quad$ All Pathogens}

8 We detected at least one pathogen in 91\% (163/179) of latrine entrance soils, two or more

9 pathogens in $75 \%(134 / 179)$, and a mean of 3.4 out of 20 measured targets (IQR=3.5). The four

10 most frequently detected pathogens were Ascaris lumbricoides (62\%, [111/179]), EAEC (46\%,

11 [82/179]), Giardia duodenalis (36\%, [64/179]), and astrovirus (26\%, [47/179]). We found

12 evidence that the intervention reduced the detection of $\geq 1$ pathogen in latrine entrance soils by

$1315 \%(\mathrm{aPR}=0.85,95 \% \mathrm{CI}[0.70,1.0])$ and the total number of pathogens by $35 \%(\mathrm{aPR}=0.65$,

$1495 \%$ CI $[0.44,0.95]$ ) (Table 2). The mean Cq values of detected pathogens were similar across

15 trial arms and phases (Table S5).

16 There was a consistent trend among all individual pathogens except for astrovirus: the adjusted

17 point estimates for nine of the ten most frequently detected had point estimates below 1.0 (Table

18 3). The confidence intervals around the adjusted DID estimates of effect were also below 1.0 for

19 three pathogen targets: Ascaris lumbricoides $(\mathrm{aPR}=0.62,95 \% \mathrm{CI}[0.39,0.98]), \mathrm{EAEC}(\mathrm{aPR}=0.51$,

$2095 \% \mathrm{CI}[0.27,0.94])$, and $\mathrm{EPEC}(\mathrm{aPR}=0.2095 \% \mathrm{CI}[0.05,0.82])$. 
Table 2. Detection of pathogens at baseline and 24-month

\begin{tabular}{|c|c|c|c|c|}
\hline Detection & & & & \\
\hline & $\begin{array}{l}\text { Baseline } \\
\text { Detection }\end{array}$ & $\begin{array}{l}\text { 24-month } \\
\text { Detection }\end{array}$ & $\begin{array}{l}\text { Unadjusted BL-24M } \\
\text { DID estimate }\end{array}$ & $\begin{array}{l}\text { Adjusted BL-24M } \\
\text { DID estimate }\end{array}$ \\
\hline \multicolumn{5}{|l|}{$\geq 1$ pathogen } \\
\hline control & $0.88(42 / 48)$ & $0.96(43 / 45)$ & \multirow{2}{*}{$\begin{array}{c}0.82(0.68,1.0) \\
p=0.05\end{array}$} & \multirow{2}{*}{$\begin{array}{c}0.85(0.70,1.0) \\
p=0.11\end{array}$} \\
\hline intervention & $0.95(41 / 43)$ & $0.86(37 / 43)$ & & \\
\hline Total pathogen detects (out of 20) & Mean (IQR) & Mean (IQR) & & \\
\hline control & $3.5(4)$ & $3.9(3)$ & \multirow{2}{*}{$\begin{array}{c}0.66(0.44,0.97) \\
p=0.03\end{array}$} & \multirow{2}{*}{$\begin{array}{c}0.65(0.44,0.95) \\
p=0.03\end{array}$} \\
\hline intervention & $3.6(3)$ & $2.6(3)$ & & \\
\hline
\end{tabular}

22 Note: DID: difference-in-difference. BL: baseline. 24M: 24-month. IQR: Inter-quartile range

Table 3. Detection of individual pathogens at baseline and 24-month. Sorted by detection in control soils at the 24-month phase.

\begin{tabular}{|c|c|c|c|c|}
\hline \multicolumn{5}{|l|}{ Pathogen } \\
\hline & $\begin{array}{l}\text { Baseline } \\
\text { Detection }\end{array}$ & $\begin{array}{l}\text { 24-month } \\
\text { Detection }\end{array}$ & $\begin{array}{l}\text { Unadjusted BL-24M } \\
\text { DID estimate } \neq\end{array}$ & $\begin{array}{l}\text { Adjusted BL-24M } \\
\text { DID estimate } \neq\end{array}$ \\
\hline \multicolumn{5}{|l|}{ Ascaris lumbricoides } \\
\hline control & $0.65(31 / 48)$ & $0.76(34 / 45)$ & \multirow{2}{*}{$\begin{array}{c}0.64(0.40,1.0) \\
p=0.06\end{array}$} & \multirow{2}{*}{$\begin{array}{c}0.62(0.39,0.98) \\
p=0.04\end{array}$} \\
\hline intervention & $0.63(27 / 43)$ & $0.44(19 / 43)$ & & \\
\hline \multicolumn{5}{|l|}{ Enteroaggregative $E$. coli } \\
\hline control & $0.42(20 / 48)$ & $0.53(24 / 45)$ & \multirow{2}{*}{$\begin{array}{c}0.57(0.30,1.1) \\
p=0.08\end{array}$} & \multirow{2}{*}{$\begin{array}{c}0.51(0.27,0.94 \\
p=0.03\end{array}$} \\
\hline intervention & $0.51(22 / 43)$ & $0.37(16 / 43)$ & & \\
\hline \multicolumn{5}{|l|}{ Giardia duodenalis } \\
\hline control & $0.42(20 / 48)$ & $0.38(17 / 45)$ & \multirow{2}{*}{$\begin{array}{c}0.76(0.34,1.7) \\
p=0.50\end{array}$} & \multirow{2}{*}{$\begin{array}{c}0.85(0.37,1.9) \\
\mathrm{p}=0.69\end{array}$} \\
\hline intervention & $0.37(16 / 43)$ & $0.26(11 / 43)$ & & \\
\hline
\end{tabular}




\begin{tabular}{|c|c|c|c|c|}
\hline Shigella/Enteroinvasive $E$. coli & & & & \multirow{3}{*}{$\begin{array}{c}0.59(0.18,1.9) \\
\mathrm{p}=0.38\end{array}$} \\
\hline control & $0.33(16 / 48)$ & $0.33(15 / 45)$ & \multirow{2}{*}{$\begin{array}{c}0.58(0.17,1.9) \\
p=0.37\end{array}$} & \\
\hline intervention & $0.16(7 / 43)$ & $0.09(4 / 43)$ & & \\
\hline \multicolumn{5}{|l|}{ Enterotoxigenic E. coli } \\
\hline control & $0.25(12 / 48)$ & $0.33(15 / 45)$ & \multirow{2}{*}{$\begin{array}{c}0.45(0.17,1.2) \\
p=0.10\end{array}$} & \multirow{2}{*}{$\begin{array}{c}0.44(0.17,1.1) \\
p=0.09\end{array}$} \\
\hline intervention & $0.35(15 / 43)$ & $0.21(9 / 43)$ & & \\
\hline \multicolumn{5}{|l|}{ adenovirus 40/41 } \\
\hline control & $0.23(11 / 48)$ & $0.33(15 / 45)$ & \multirow{2}{*}{$\begin{array}{c}0.34(0.08,1.5) \\
p=0.19\end{array}$} & \multirow{2}{*}{$\begin{array}{c}0.32(0.07,1.5) \\
p=0.14\end{array}$} \\
\hline intervention & $0.14(6 / 43)$ & $0.07(3 / 43)$ & & \\
\hline \multicolumn{5}{|l|}{ astrovirus } \\
\hline control & $0.23(11 / 48)$ & $0.27(12 / 45)$ & \multirow{2}{*}{$\begin{array}{c}1.3(0.51,3.1) \\
p=0.62\end{array}$} & \multirow{2}{*}{$\begin{array}{c}1.6(0.60,4.0) \\
p=0.36\end{array}$} \\
\hline intervention & $0.23(10 / 43)$ & $0.33(14 / 43)$ & & \\
\hline \multicolumn{5}{|l|}{ Enteropathogenic E. coli } \\
\hline control & $0.15(7 / 48)$ & $0.24(11 / 45)$ & \multirow{2}{*}{$\begin{array}{c}0.20(0.05,0.88) \\
p=0.02\end{array}$} & \multirow{2}{*}{$\begin{array}{c}0.20(0.05,0.82) \\
p=0.03\end{array}$} \\
\hline intervention & $0.21(9 / 43)$ & $0.07(3 / 43)$ & & \\
\hline \multicolumn{5}{|l|}{ Trichuris trichiura } \\
\hline control & $0.31(15 / 48)$ & $0.18(8 / 45)$ & \multirow{2}{*}{$\begin{array}{c}1.0(0.33,3.2) \\
\mathrm{p}=0.96\end{array}$} & \multirow{2}{*}{$\begin{array}{c}0.95(0.32,2.9) \\
\mathrm{p}=0.93\end{array}$} \\
\hline intervention & $0.28(12 / 43)$ & $0.16(7 / 43)$ & & \\
\hline \multicolumn{5}{|l|}{ Clostridium difficile } \\
\hline control & $0.13(6 / 48)$ & $0.16(7 / 45)$ & \multirow{2}{*}{$\begin{array}{c}0.68(0.17,2.8) \\
p=0.59\end{array}$} & \multirow{2}{*}{$\begin{array}{c}0.70(0.16,3.0) \\
p=0.62\end{array}$} \\
\hline intervention & $0.16(7 / 43)$ & $0.14(6 / 43)$ & & \\
\hline \multicolumn{5}{|l|}{ Cryptosporidium parvum } \\
\hline $\begin{array}{ll} & \text { control } \\
\end{array}$ & $0.02(1 / 48)$ & $0.09(4 / 45)$ & \multirow[t]{2}{*}{ NA } & \\
\hline intervention & $0.11(5 / 43)$ & $0.07(3 / 43)$ & & \\
\hline \multicolumn{5}{|l|}{ Salmonella spp. } \\
\hline control & $0.02(1 / 48)$ & $0.09(4 / 45)$ & \multirow[t]{2}{*}{ NA } & \\
\hline intervention & $0.05(2 / 43)$ & $0.05(2 / 43)$ & & \\
\hline \multicolumn{5}{|l|}{ Shiga-toxin producing $E$. coli } \\
\hline $\begin{array}{ll}\text { control } \\
\end{array}$ & $0.02(1 / 48)$ & $0.07(3 / 45)$ & \multirow[t]{2}{*}{ NA } & \\
\hline intervention & $0(0 / 43)$ & $0.02(1 / 43)$ & & \\
\hline Campylobacter jejuni/coli & & & & \\
\hline
\end{tabular}




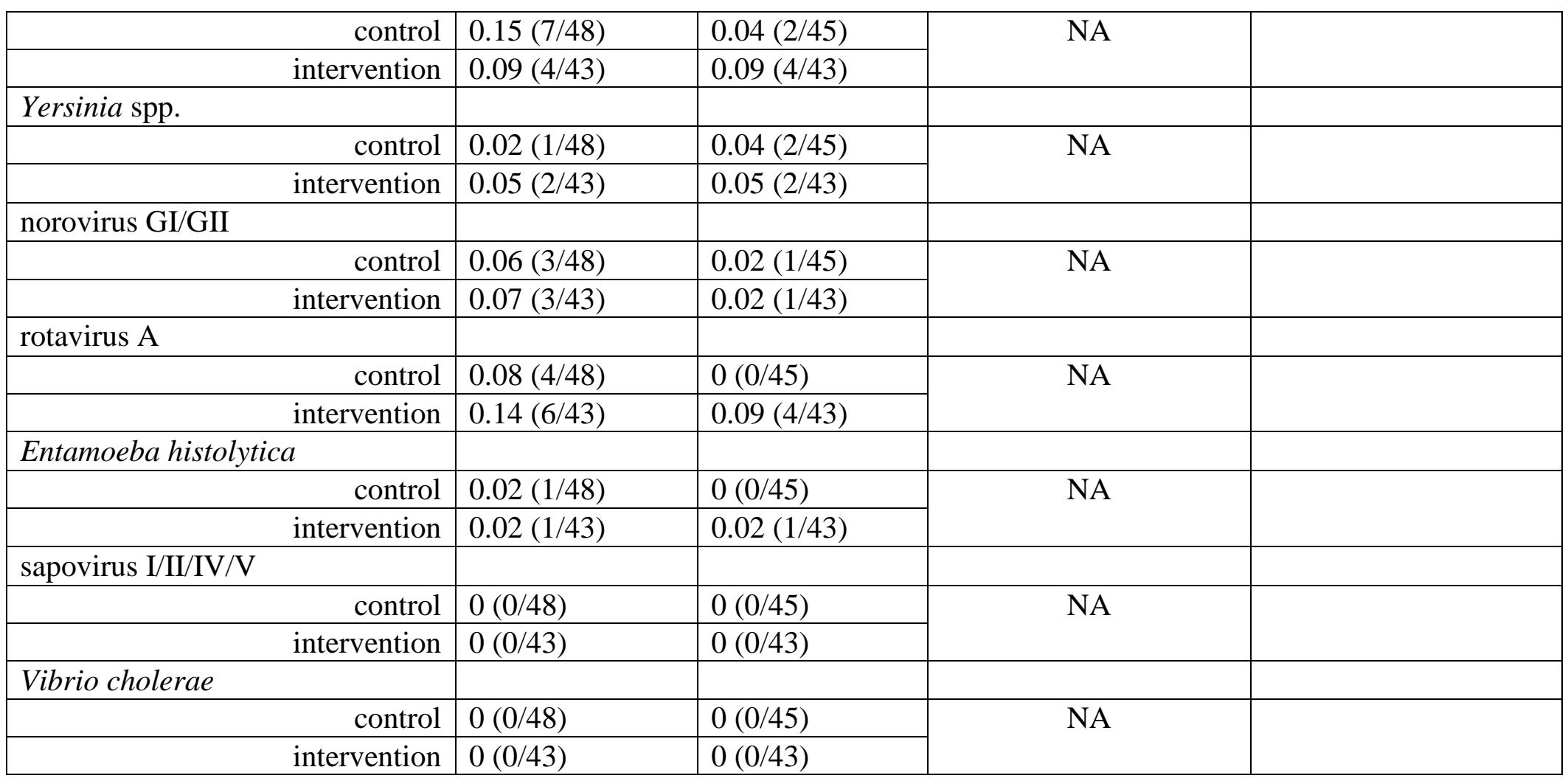

25 Note: DID: difference-in-difference.

$26 \neq$ We did not calculate DID estimates for pathogens with $<5 \%$ detection 


\section{DISCUSSION}

30 We found evidence that the onsite shared urban sanitation intervention evaluated in the MapSan

31 trial was somewhat protective against the detection of $\geq 1$ pathogen and against the total number

32 of pathogens in latrine entrance soils. The adjusted estimates for nine of the ten most common

33 pathogens were consistently protective (DID estimates $=0.20-0.95$ ) and pathogen-specific effect

34 estimates from adjusted models were protective for Ascaris lumbricoides, EAEC, and EPEC.

35 This suggests that intervention septic tanks may have better sequestered or inactivated these

36 pathogens, which are passed in stool, compared with controls.

37 Most of the other pathogens we frequently detected in soils were measured in child stools via

38 multiplex end-point PCR as part of the MapSan trial, with the exception of EAEC, EPEC, and

39 astrovirus. At baseline, Shigella/EIEC (44\%) and Trichuris trichiura (37\%) - generally thought

40 to be transmitted human-to-human - were the second and third most common pathogens detected

41 in child stool ${ }^{24,50}$, following Giardia $(51 \%)$ which can be zoonotic ${ }^{70}$. Given the high prevalence

42 of anthroponotic enteric pathogens in stools and the lack of a zoonotic reservoir for

43 Shigella/EIEC and Trichuris trichiura ${ }^{71,72}$, the trial may have had greater power to observe an

44 effect on Shigella/EIEC and Trichuris trichiura compared with other pathogens. For children

45 born into study compounds before the 24-month visit, the intervention reduced the detection of

46 Shigella/EIEC in children's stools by $51 \%$ and Trichuris trichiura by $76 \% .{ }^{58}$ Results from soils

47 in this study differ from trial findings in stools: while we observed a $41 \%$ reduction in

48 Shigella/EIEC detection, we identified no difference with respect to detection of Trichuris

49 trichiura. This absence of impact on Trichuris trichiura in soils may have been due to limited 
50 power from infrequent detection; we did observe a reduction in the other STH assessed, Ascaris

51 lumbricoides, which was the most frequently detected individual pathogen in soils. The MapSan

52 trial found the sanitation intervention reduced the detection of Ascaris lumbricoides by $32 \%$

53 among children born into study compounds before the 24-month visit, but the confidence interval

54 included the null. ${ }^{58}$ Overall, the protective trend we observed in soils, therefore, is consistent

55 with the enteric infection data for children born into trial compounds. This may suggest that the

56 intervention reduced the transport of pathogens to latrine entrance soils, and subsequently

57 contributed to a reduction in children's exposures, but our small sample size and the resulting

58 uncertainty of point estimates suggest results should be interpreted with caution.

59 Compared to other recent large-scale, rigorous trials of onsite sanitation improvements in rural

60 Bangladesh (pour flush to double-pit latrine) $)^{2}$, rural Kenya (single unlined pit latrine with plastic

61 slab and hole-lid) ${ }^{3}$, and rural Zimbabwe (ventilated improved pit latrine $)^{4}$, we evaluated a more

62 sophisticated intervention that included site-specific engineered septic tanks and subsurface

63 discharge of aqueous effluent to a soakaway $\mathrm{pit}^{24,73}$, and it is the only recent controlled health

64 impact trial of onsite sanitation to take place in an urban setting. In the early 2000s, Barreto et al.

65 observed health benefits from household sewerage connections in urban Brazil in an

66 uncontrolled trial ${ }^{74,75}$. However, the scope, complexity, and cost of that intervention make it an

67 imperfect point of comparison.

68 The WASH Benefits Trial (WASH-B) evaluated the impact of single and combined water,

69 sanitation, and handwashing intervention arms in rural Bangladesh and Kenya. In Bangladesh, a

70 molecular analysis of household entrance soils, hand rinses, and stored water from the sanitation

71 arm found no significant reductions in enteric pathogens (EAEC, EPEC, STEC, Shigella/EIEC,

72 ETEC, norovirus, Cryptosporidium spp., Giardia duodenalis) or microbial source tracking 
73 markers (HumM2, BacCow). ${ }^{38}$ The combined WASH arm and individual water treatment arm

74 observed a reduction in E. coli prevalence and concentration in stored drinking water; the

75 individual water treatment and handwashing arms reduced E. coli prevalence and concentration

76 in food. WASH-B trial arms in Bangladesh did not observe reductions in E. coli in courtyard

77 soil, ambient waters, child hands, or sentinel objects. ${ }^{76,77}$ Likewise, WASH-B Kenya found the

78 individual water treatment arm and combined WASH arm reduced culturable $E$. coli in stored

79 drinking water, but not along other transmission pathways. ${ }^{18}$ The Sanitation, Hygiene, Infant

80 Nutrition Efficacy Project (SHINE) trial in rural Zimbabwe has not yet published the results

81 from a sub-study on environmental fecal contamination. In separate analyses of environmental

82 samples collected during MapSan baseline ${ }^{15}$ and the 24-month phase $\mathrm{e}^{13,21,44}$ we found widespread

83 fecal contamination in soils and other environmental compartments. At the 12-month MapSan

84 trial phase Holcomb et al. 2021 found the intervention reduced E. coli gene densities by more

85 than 1- $\log _{10}$ in latrine entrance soils, but observed no reduction in culturable $E$. coli or human

86 microbial source tracking markers. ${ }^{78}$ Our study is the first controlled evaluation of an urban

87 onsite sanitation intervention to show a decrease in the detection of enteric pathogens, via

88 molecular methods, in soils from the domestic living environment.

89 The intervention may have reduced the presence of enteric pathogens in soils compared with

90 controls because the intervention may have better sequestered or treated fecal material than

91 control latrines. In high-income countries, properly designed, constructed, and maintained septic

92 tank systems have been demonstrated to be efficient and economic alternatives to public sewage

93 disposal systems. ${ }^{79}$ Although some pathogen die-off will occur in pit latrines, the primary

94 purpose of pit latrines is to sequester human feces and reduce exposures, and they are not

95 designed to achieve a specific level of pathogen reduction. ${ }^{80}$ Design features of the intervention 
96 septic tanks may have resulted in better treatment of fecal wastes than control systems.

97 Intervention septic tanks contained inlet and outlet pipes configured to maximize detention time,

98 baffles to direct incoming waste downward, t-pipes to ensure sequestration of solids and

99 floatable materials, and a sealed containment chamber to promote anaerobic treatment of stored

100 solids and non-settleable materials. In addition, the intervention septic tank systems represented

101 an upgrade to a more permanent sanitation infrastructure. The construction included masonry

102 block walls, a concrete floor, masonry block lined septic tank, masonry block lined soakaway pit,

103 tin roof, and a water seal squat pan. ${ }^{20,24,53,73}$ These features may have acted as a physical barrier

104 that prevented the contamination of soils by enteric pathogens. At the 24-month phase, most

105 control compounds used a pit latrine with or without a slab, and therefore lacked similar physical

106 barriers such as a water seal. In addition, the control compounds that did upgrade to pour flush

107 sanitation may not have used the same rigorous design criteria as intervention septic tanks. ${ }^{50}$

108 The extent to which bacterial and viral pathogens may be transported from fecal sludges through

109 the surrounding soil depends on pit characteristics including presence of lining ${ }^{32}$ and the

110 hydrological and soil conditions. ${ }^{31}$ Protozoan cysts and helminth ova are unlikely to be

111 transported out of the pit and into surrounding soil because of their relatively large size. ${ }^{80-82}$

112 Lateral movement of viral pathogens from unlined or partially lined pit latrines to groundwater

113 has been demonstrated at distances up to 50 meters. $^{31,83}$ This movement is often exacerbated by a

114 high water table ${ }^{31}$, which is present in the study neighborhoods. ${ }^{53}$ While we were unable to

115 assess the lining of control latrines, it is unlikely control linings - if present - matched the

116 construction quality of intervention linings.

117 Pit latrines in low-income Maputo are often covered when full and rebuilt, or the fecal sludge is

118 emptied and buried or dumped nearby. ${ }^{20}$ The intervention included programming to encourage 
119 hygienic pit emptying and provided equipment and training to local organizations to offer

120 hygienic emptying services. ${ }^{73}$ During the 24 -month phase, intervention compounds emptied their

121 sanitation systems less frequently and were more likely to have their onsite systems emptied

122 hygienically than control compounds. ${ }^{20}$ Less frequent emptying would have beneficial for two

123 reasons. First, longer residence times would likely have resulted in greater pathogen die-off. ${ }^{80}$

124 Second, less frequent emptying would have created fewer opportunities for environmental fecal

125 contamination to occur and hygienic emptying may have reduced the quantity of fecal sludge

126 that contaminated soils during emptying. In addition, intervention systems contained a drain for

127 bathing, which may have prevented fecally contaminated graywater from flowing into nearby

128 soils, and the concrete floors were likely easier to clean than control systems with dirt floors. ${ }^{56}$

129 Although our findings suggest that some pathogens appeared to be reduced by the latrine

130 improvements, it is likely that the potential for exposure remains high in this setting. ${ }^{13}$ While we

131 detected some individual pathogens, such as Ascaris lumbricoides, EAEC, Shigella/EIEC and

132 EPEC, in intervention soils less frequently compared to controls during the 24-month phase, we

133 also detected one or more enteric pathogens in $86 \%$ of intervention latrine entrance soils two

134 years post-intervention. Fecal waste from children unable to use the latrines was not addressed

135 by the intervention. ${ }^{28,84}$ At the 24-month follow-up, 29\% (289/980) of children reported

136 defecating into a latrine, 29\% (281/980) defecated into a child potty which was emptied into a

137 latrine, 20\% (192/980) used disposable diapers that were disposed with solid waste, 7.3\%

138 defecated on the ground (72/980), and 2.7\% (26/980) defecated into diapers that were washed

139 and reused (Table S6). In addition, the intervention did not address animal feces. While we

140 adjusted for animals in our DID estimates, many animals are not penned in this setting and may

141 defecate outside of their respective compounds, which was not accounted for in our analysis. ${ }^{30}$ 
142 Live chickens are also commonly purchased and stored in the compound for consumption. ${ }^{85} \mathrm{We}$

143 may not have adequately captured this intermittent chicken ownership in our cross-sectional

144 surveys.

145 The similar reduction in pathogen detection in soils and child stools may be informative about

146 exposures. At two years post-intervention in the MapSan cohort, children born into study

147 compounds were 1-24 months old, while children born previously and enrolled at baseline were

$148 \quad 25-73$ months old. ${ }^{58}$ Considering the consistent reduction in the detection of pathogens observed

149 in soils and stools from children 1-24 months old, the dominant exposure pathways for these

150 younger children may be inside the compound or soil ingestion may have represented a more

151 important transmission pathway for these children. ${ }^{86}$ Older children are more mobile than

152 younger children, and their potential exposures outside of study compounds may explain why the

153 intervention did not reduce the prevalence of pathogen carriage among them.

154 Our study had several limitations, including a relatively small sample size that was not intended

155 to observe small reductions in pathogen detection. Nevertheless, in high burden settings,

156 sanitation interventions may need to achieve a large reduction in environmental fecal

157 contamination both within households and in the larger community to reduce exposure risks and

158 yield improved health outcomes. ${ }^{87}$ Further, intervention compounds had lower wealth indices

159 and higher compound populations 24-months post intervention compared to control. This may

160 suggest we underestimated changes due to sanitation improvements, but we adjusted for these in

161 our regression analyses and did not observe substantial differences between unadjusted and

162 adjusted point estimates that would indicate confounding. In addition, we assessed gene targets

163 via molecular assays - which may not be $100 \%$ sensitive or specific $61,88,89$ - and not pathogen

164 viability or infectivity. 
165 There is substantial evidence that city-wide upgrades to sewerage infrastructure improve health

166 outcomes. $^{74,75,90}$ However, the high capital and maintenance costs ${ }^{91}$, and water usage

167 requirements ${ }^{92}$ of such improvements suggest they are currently impractical for many LMICs.

168 Until sewerage becomes widely feasible in high-burden settings, onsite sanitation systems

169 remain necessary to achieve safely managed sanitation in many urban areas. The results of this

170 study - and other rigorous environmental impact evaluations of onsite sanitation

171 interventions ${ }^{18,38,77}$ - suggest that fecal contamination is transported into the environment

172 through multiple complex pathways that may vary among settings. ${ }^{93}$ In urban Maputo - and

173 similar settings with poor sanitation infrastructure, widespread environmental fecal

174 contamination, and a high burden of enteric infection - other, more transformative interventions

175 interrupting multiple transmission pathways may need to accompany improvements to onsite

176 sanitation infrastructure. These improvements likely require an integrated and incremental

177 approach that might include legal protections (e.g. land tenure) ${ }^{94}$, contact control interventions

178 (e.g. hardscape cleanable flooring $)^{13,95,96}$, public infrastructure (e.g. drainage, and improvements

179 in quality, quantity, and access to water) ${ }^{97}$, and public services (e.g. education, hygienic fecal

180 sludge and solid waste management $)^{20,98,99}$. Such improvements may reduce the transport of

181 enteric pathogens into the environment through site-specific pathways and subsequently reduce

182 children's infection risks.

\section{Supplemental Information}

184 1. Text S1. Detailed description of the sanitation intervention

1852 2. Text S2. Compound enrollment at baseline

186 3. Text S3. Test for Matrix Inhibition

187 4. Text S4. Custom TaqMan Array Card (TAC) 
5. Table S1. Assays used on the custom TAC

6. Table S2. Interpretation of gene targets on the TAC

1907 7. Table S3. Description of variables and their respective sources

191 8. Table S4. Soils samples matched at baseline and 24-month trial periods

192 9. Figure S1. Histogram of dates that latrine entrance soils were collected

193 10. Table S5. Mean Cq Values

194 11. Table S6. Child feces disposal at 24-month phase

195 Notes

196 The findings and conclusions in this report are those of the authors and do not necessarily represent

197 the official position of the Centers for Disease Control and Prevention. 


\section{References}

(1) Wagner, E.; Lanoix, J. Excreta Disposal for Rural Areas and Small Communities. Monogr Ser World Heal. Organ. 1958, 39, 1-182.

(2) Luby, S. P.; Rahman, M.; Arnold, B. F.; Unicomb, L.; Ashraf, S.; Winch, P. J.; Stewart, C. 109X(17)30490-4.

(3) Null, C.; Stewart, C. P.; Pickering, A. J.; Dentz, H. N.; Arnold, B. F.; Arnold, C. D.;

Diarrhoea and Child Growth in Rural Kenya: A Cluster-Randomised Controlled Trial.

Lancet Glob. Heal. 2018, 6 (3), e316-e329. https://doi.org/10.1016/S2214-

(4) Humphrey, J. H.; Mbuya, M. N. N.; Ntozini, R.; Moulton, L. H.; Stoltzfus, R. J.; Tavengwa, 109X(18)30005-6. 
Nyamupfukudza, J.; Saidi, B.; Sakuhwehwe, T.; Sikalima, G.; Tembe, J.; Chekera, T. E.; 
Kaswa, T.; Kayeruza, P.; Lunga, J.; Magogo, N.; Manyeruke, D.; Mazani, P.; Mhuriyengwe,

F.; Mlambo, F.; Moyo, S.; Mpofu, T.; Mugava, M.; Mukungwa, Y.; Muroyiwa, F.;

Chingozho, M.; Chinhamo, O.; Chinokuramba, R.; Chinyoka, C.; Chipenzi, X.; Chipute,

Makumbe, R.; Mandire, M.; Mandiyanike, E.; Mangena, E.; Mangiro, F.; Mangwadu, A.; Mangwengwe, T.; Manhidza, J.; Manhovo, F.; Manono, I.; Mapako, S.; Mapfumo, E.; 
Mapfumo, T.; Mapuka, J.; Masama, D.; Masenge, G.; Mashasha, M.; Mashivire, V.;

Matunhu, M.; Mavhoro, P.; Mawuka, G.; Mazango, I.; Mazhata, N.; Mazuva, D.; Mazuva, 
Marecha, S.; Mashiri, C.; Masiya, M.; Masuku, T.; Masvimbo, P.; Matambo, S.; Matarise,

Muteya, E.; Muvembi, S.; Muzenda, T.; Mwenjota, A.; Ncube, S.; Ndabambi, T.; Ndava,

Habicht, J.-P.; Masimirembwa, C.; Morgan, P.; Pelto, G. H.; Sheffner-Rogers, C.; Thelingwani, R.; Turner, P.; Zungu, L.; Makadzange, T.; Mujuru, H. A.; Nyachowe, C.; 
Chakadai, R.; Chanyau, G.; Makamure, M. G.; Chiwariro, H.; Mtetwa, T.; Chikunya, J.;

Maguwu, L.; Nyadundu, S.; Moyo, T.; Chayima, B.; Mvindi, L.; Rwenhamo, P.;

Muzvarwandoga, S.; Chimukangara, R.; Njovo, H.; Makoni, T. Independent and Combined

Effects of Improved Water, Sanitation, and Hygiene, and Improved Complementary

Feeding, on Child Stunting and Anaemia in Rural Zimbabwe: A Cluster-Randomised Trial.

Lancet Glob. Heal. 2019, 7 (1), e132-e147. https://doi.org/10.1016/S2214-

(5) Clasen, T.; Boisson, S.; Routray, P.; Torondel, B.; Bell, M.; Cumming, O.; Ensink, J.;

Freeman, M.; Jenkins, M.; Odagiri, M.; Ray, S.; Sinha, A.; Suar, M.; Schmidt, W. P.

Infection, and Child Malnutrition in Odisha, India: A Cluster-Randomised Trial. Lancet

Glob. Heal. 2014, 2 (11), e645-e653. https://doi.org/10.1016/S2214-109X(14)70307-9.

(6) Patil, S. R.; Arnold, B. F.; Salvatore, A. L.; Briceno, B.; Ganguly, S.; Colford, J. M.; Gertler,

(7) Pickering, A. J.; Djebbari, H.; Lopez, C.; Coulibaly, M.; Alzua, M. L. Effect of a

(8) Goddard, F. G. B.; Ban, R.; Barr, D. B.; Brown, J.; Cannon, J.; Colford, J. M.; Eisenberg, 
Pickering, A. J.; Sarnat, J. A.; Stewart, J.; Thomas, E.; Taniuchi, M.; Clasen, T. Measuring

Environmental Exposure to Enteric Pathogens in Low-Income Settings: Review and

Recommendations of an Interdisciplinary Working Group. Environmental Science and

Technology. American Chemical Society October 6, 2020, pp 11673-11691.

(9) Mattioli, M. C. M.; Davis, J.; Boehm, A. B. Hand-to-Mouth Contacts Result in Greater

Ingestion of Feces than Dietary Water Consumption in Tanzania: A Quantitative Fecal

Exposure Assessment Model. Environ. Sci. Technol. 2015, 49 (3), 1912-1920. https://doi.org/10.1021/es505555f.

(10) Katukiza, A. Y.; Ronteltap, M.; van der Steen, P.; Foppen, J. W. A.; Lens, P. N. L.

Quantification of Microbial Risks to Human Health Caused by Waterborne Viruses and

Bacteria in an Urban Slum. J. Appl. Microbiol. 2014, 116 (2), 447-463.

(11) Cairncross, S.; Blumenthal, U.; Kolsky, P.; Moraes, L.; Tayeh, A. The Public and Domestic https://doi.org/10.1111/jam.12368.

Domains in the Transmission of Disease. Trop. Med. Int. Heal. 1996, 1 (1), 27-34.

(12) Baker, K. K.; Senesac, R.; Sewell, D.; Sen Gupta, A.; Cumming, O.; Mumma, J. Fecal https://doi.org/10.1046/j.1365-3156.1996.d01-9.x. 
Risk Assessment of Pediatric Infections Attributable to Ingestion of Fecally Contaminated

Domestic Soils in Low-Income Urban Maputo, Mozambique. Environ. Sci. Technol. 2021, 55 (3), 1941-1952. https://doi.org/10.1021/acs.est.0c06972.

(14) Steinbaum, L.; Njenga, S. M.; Kihara, J.; Boehm, A. B.; Davis, J.; Null, C.; Pickering, A. J. Soil-Transmitted Helminth Eggs Are Present in Soil at Multiple Locations within

Households in Rural Kenya. PLoS One 2016, 11 (6), e0157780.

(15) Holcomb, D. A.; Knee, J.; Sumner, T.; Adriano, Z.; de Bruijn, E.; Nalá, R.; Cumming, O.;

Brown, J.; Stewart, J. R. Human Fecal Contamination of Water, Soil, and Surfaces in

Households Sharing Poor-Quality Sanitation Facilities in Maputo, Mozambique. Int. J. Hyg.

Environ. Health 2020, 226, 113496. https://doi.org/10.1016/j.ijheh.2020.113496.

(16) Pickering, A. J.; Julian, T. R.; Marks, S. J.; Mattioli, M. C.; Boehm, A. B.; Schwab, K. J.;

Davis, J. Fecal Contamination and Diarrheal Pathogens on Surfaces and in Soils among Tanzanian Households with and without Improved Sanitation. Environ. Sci. Technol. 2012,

(17) Ercumen, A.; Pickering, A. J.; Kwong, L. H.; Mertens, A.; Arnold, B. F.; Benjamin-Chung, J.; Hubbard, A. E.; Alam, M.; Sen, D.; Islam, S.; Rahman, M. Z.; Kullmann, C.; Chase, C.; Ahmed, R.; Parvez, S. M.; Unicomb, L.; Rahman, M.; Ram, P. K.; Clasen, T.; Luby, S. P.; Colford, J. M. Do Sanitation Improvements Reduce Fecal Contamination of Water, Hands, 
(18) Pickering, A. J.; Swarthout, J.; Mureithi, M.; Mboya, J.; Arnold, B. F.; Wolfe, M.; Dentz,

M.; Null, C. Can Individual and Integrated Water, Sanitation, and Handwashing https://doi.org/10.1101/731992.

(19) World Health Organization. Guidelines on Sanitation and Health; Geneva, 2018.

(20) Capone, D.; Buxton, H.; Cumming, O.; Dreibelbis, R.; Knee, J.; Nalá, R.; Ross, I.; Brown,

J. Impact of an Intervention to Improve Pit Latrine Emptying Practices in Low Income

(21) Capone, D.; Berendes, D.; Cumming, O.; Knee, J.; Nalá, R.; Risk, B. B.; Stauber, C.; Zhu, https://doi.org/10.1016/j.ijheh.2020.113480.

K.; Brown, J. Analysis of Fecal Sludges Reveals Common Enteric Pathogens in Urban Maputo, Mozambique. Environ. Sci. Technol. Lett. 2020.

(22) Alexander, K. A.; Godrej, A. Greywater Disposal Practices in Northern Botswana--The Silent Spring? Int. J. Environ. Res. Public Health 2015, 12 (11), 14529-14540. https://doi.org/10.3390/ijerph121114529.

(23) Carden, K.; Armitage, N.; Sichone, O.; Winter, K. The Use and Disposal of Greywater in the Non-Sewered Areas of South Africa: Part 2 - Greywater Management Options. Water SA 2010, 33 (4). https://doi.org/10.4314/wsa.v33i4.52936. 
(24) Knee, J.; Sumner, T.; Adriano, Z.; Berendes, D.; de Bruijn, E.; Schmidt, W.-P.; Nalá, R.; https://doi.org/10.1371/journal.pntd.0006956.

(25) Miller-Petrie, M. K.; Voigt, L.; McLennan, L.; Cairncross, S.; Jenkins, M. W. Infant and Young Child Feces Management and Enabling Products for Their Hygienic Collection, https://doi.org/10.4269/ajtmh.15-0423.

(26) Borges Pedro, J. P.; Oliveira, C. A. da S.; de Lima, S. C. R. B.; von Sperling, M. A Review of Sanitation Technologies for Flood-Prone Areas. J. Water, Sanit. Hyg. Dev. 2020, 10 (3), 397-412. https://doi.org/10.2166/washdev.2020.019.

(27) Levy, K.; Woster, A. P.; Goldstein, R. S.; Carlton, E. J. Untangling the Impacts of Climate 50 (10), 4905-4922. https://doi.org/10.1021/acs.est.5b06186.

(28) Penakalapati, G.; Swarthout, J.; Delahoy, M. J.; McAliley, L.; Wodnik, B.; Levy, K.; Freeman, M. C. Exposure to Animal Feces and Human Health: A Systematic Review and https://doi.org/10.1021/acs.est.7b02811. 
https://doi.org/10.1038/s41893-018-0167-0.

(30) Delahoy, M. J.; Wodnik, B.; McAliley, L.; Penakalapati, G.; Swarthout, J.; Freeman, M. C.;

Levy, K. Pathogens Transmitted in Animal Feces in Low- and Middle-Income Countries.

Int. J. Hyg. Environ. Health 2018, 221

(4), $\quad$ 661-676.

https://doi.org/10.1016/j.ijheh.2018.03.005.

(31) Graham, J. P.; Polizzotto, M. L. Pit Latrines and Their Impacts on Groundwater Quality: A

Systematic Review. Environmnetal Heal. Perspect. 2013, 5 (121), 521-530. https://doi.org/10.1289/ehp.1206028.

(32) Nichols, D. S.; Prettyman, D.; Gross, M. Movement of Bacteria and Nutrients from Pit (2), 171-180. https://doi.org/10.1007/BF00279627.

(33) Chaúque, B. J. M.; Chicumbe, C. M.; Cossa, V. C.; Rott, M. B. Spatial Arrangement of

(34) Wang, Y.; Moe, C. L.; Null, C.; Raj, S. J.; Baker, K. K.; Robb, K. A.; Yakubu, H.; Ampofo, Children in Low-Income Urban Environments in Accra, Ghana: The Sanipath Analytical Approach. Am. J. Trop. Med. Hyg. 2017, 97 (4), 1009-1019. https://doi.org/10.4269/ajtmh.16-0408. 
(35) Kwong, L. H.; Ercumen, A.; Pickering, A. J.; Unicomb, L.; Davis, J.; Leckie, J. O.; Luby,

(36) Ercumen, A.; Pickering, A. J.; Kwong, L. H.; Arnold, B. F.; Parvez, S. M.; Alam, M.; Sen,

(38) Fuhrmeister, E. R.; Ercumen, A.; Pickering, A. J.; Jeanis, K. M.; Crider, Y.; Ahmed, M.; on Pathogens and Microbial Source Tracking Markers in the Rural Bangladeshi Household Environment. Cite This Environ. Sci. Technol 2020, 54, 4316-4326. 
(40) Pickering, A. J.; Ercumen, A.; Arnold, B. F.; Kwong, L. H.; Parvez, S. M.; Alam, M.; Sen,

(41) Ngure, F. M.; Humphrey, J. H.; Mbuya, M. N. N.; Majo, F.; Mutasa, K.; Govha, M.;

(4), 709-716. https://doi.org/10.4269/ajtmh.12-0568.

(42) Navab-Daneshmand, T.; Friedrich, M. N. D.; Gächter, M.; Montealegre, M. C.; Mlambo,

(43) Sclar, G. D.; Penakalapati, G.; Amato, H. K.; Garn, J. V.; Alexander, K.; Freeman, M. C.;

(3), 803-813. https://doi.org/10.4269/ajtmh.17-0521. of Fecal Exposure along Principal Transmission Pathways: A Systematic Review. Int. J. 
Knee, J.; Ross, I.; Brown, J. A Localized Sanitation Status Index as a Proxy for Fecal

Contamination in Urban Maputo, Mozambique. PLoS One 2019, 14 (10). https://doi.org/10.1371/journal.pone.0224333.

(45) Montealegre, M. C.; Roy, S.; Böni, F.; Hossain, M. I.; Navab-Daneshmand, T.; Caduff, L.;

(46) Odagiri, M.; Schriewer, A.; Daniels, M. E.; Wuertz, S.; Smith, W. A.; Clasen, T.; Schmidt,

Microbiol. 2006, 72 (1), 612-621. https://doi.org/10.1128/AEM.72.1.612.

(48) Byappanahalli, M. N.; Yan, T.; Hamilton, M. J.; Ishii, S.; Fujioka, R. S.; Whitman, R. L.; Sadowsky, M. J. The Population Structure of Escherichia Coli Isolated from Subtropical and Temperate Soils. Sci. Total Environ. 2012, 417-418, 273-279. https://doi.org/10.1016/j.scitotenv.2011.12.041. 
Whole Genome Sequencing. PLoS One 2021, $16 \quad$ (1), e0245910. https://doi.org/10.1371/journal.pone.0245910.

(50) Knee, J.; Sumner, T.; Adriano, Z.; Anderson, C.; Capone, D.; Eng, B.; Casmo, V.; Holcomb, D.; Macdougall, A.; Molotkova, E.; Monteiro Braga, J.; Russo, C.; Peter Schmidt, W.; medRxiv 2020. https://doi.org/10.1101/2020.08.20.20178608.

(51) Brown, J.; Cumming, O.; Bartram, J.; Cairncross, S.; Ensink, J.; Holcomb, D.; Knee, J.; Kolsky, P.; Liang, K.; Liang, S.; Nala, R.; Norman, G.; Rheingans, R.; Stewart, J.; Zavale, https://doi.org/10.1136/bmjopen-2015-008215.

(52) Augusto, G.; Nalá, R.; Casmo, V.; Sabonete, A.; Mapaco, L.; Monteiro, J. Geographic Distribution and Prevalence of Schistosomiasis and Soil-Transmitted Helminths among Schoolchildren in Mozambique. Am. J. Trop. Med. Hyg. 2009, 81 (5), 799-803. https://doi.org/10.4269/ajtmh.2009.08-0344.

(53) Capone, D.; Adriano, Z.; Berendes, D.; Cumming, O.; Dreibelbis, R.; Holcomb, D. A.; 
(54) Vicente, E. M.; Jermy, C. A.; Schreiner, H. D. Urban Geology of Maputo, Mocambique. In 10th Congress of the International Association for Engineering Geology and the Environment; London Geological Society: London, 2006.

(55) Bition, G.; Harvey, R. W. Transport of Pathogens through Soils and Aquifers. Environ. Microbiol. 1992, 103-124.

(56) Abu-Ashour, J.; Joy, D. M.; Lee, H.; Whiteley, H. R.; Zelin, S. Transport of Microorganisms through Soil. Water, Air, Soil Pollut. 1994, 75 (1-2), 141-158.

(57) Williams, A. R.; Overbo, A. Unsafe Return of Human Excreta to the Environment: A Literature Review; 2015.

(58) Knee, J. S. Quantifying the Impact of an Urban Onsite Shared Sanitaiton Intervention on Child Health in Maputo, Mozambique: The MapSan Trial, Georgia Institute of Technology, (Moisture) Content of Soil and Rock by Mass; 1998.

(60) Aoyagi, K.; Livak, K. J. Methods Using Exogenous, Internal Controls and Analogue Blocks 2019. 
(2), 472-480. https://doi.org/10.1128/JCM.02658-12.

(62) Capone, D.; Berendes, D.; Cumming, O.; Knee, J.; Nalá, R.; Risk, B. B.; Stauber, C.; Zhu, K.; Brown, J. Analysis of Fecal Sludges Reveals Common Enteric Pathogens in Urban Maputo, Mozambique. Environ. Sci. Technol. Lett. 2020, acs.estlett.0c00610. https://doi.org/10.1021/acs.estlett.0c00610.

(63) Kodani, M.; Winchell, J. M. Engineered Combined-Positive-Control Template for RealTime Reverse Transcription-PCR in Multiple-Pathogen-Detection Assays. J. Clin. Microbiol. 2012, 50 (3), 1057-1060. https://doi.org/10.1128/JCM.05987-11.

(64) Capone, D.; Chigwechokha, P.; de los Reyes, F. L.; Holm, R. H.; Risk, B. B.; Tilley, E.; Brown, J. Impact of Sampling Depth on Pathogen Detection in Pit Latrines. PLoS Negl. Trop. Dis. 2021, 15 (3), e0009176. https://doi.org/10.1371/journal.pntd.0009176.

(65) Wing, C.; Simon, K.; Bello-Gomez, R. A. Designing Difference in Difference Studies: Best Practices for Public Health Policy Research. Annu. Rev. Public Health 2018, 39 (1), 453469. https://doi.org/10.1146/annurev-publhealth-040617-013507.

(66) Halekoh, U.; Højsgaard, S.; Yan, J. The R Package Geepack for Generalized Estimating Equations. J. Stat. Softw. 2006, 15 (2), 1-11.

(67) Bottomley, C.; Kirby, M. J.; Lindsay, S. W.; Alexander, N. Can the Buck Always Be Passed to the Highest Level of Clustering? BMC Med. Res. Methodol. 2016, 16, 29. https://doi.org/10.1186/s12874-016-0127-1.

(68) Rose, J.; Jiménez-Cisneros, B.; Murphy, H. Persistence of Pathogens in Sewage and Other 
Water Types. In Global Water Pathogen Project; Michigan State University, 2019. https://doi.org/10.14321/waterpathogens.51.

(69) Schreiner, M. Simple Poverty Scorecard ® Poverty-Assessment Tool Mozambique; 2013.

(70) Yaoyu, F.; Xiao, L. Zoonotic Potential and Molecular Epidemiology of Giardia Species and Giardiasis. Clin. Microbiol. Rev. 2011, $24 \quad$ (1), 110-140. https://doi.org/10.1128/CMR.00033-10.

(71) Izurieta, R.; Reina-Ortiz, M.; Ochoa-Capello, T. Trichuris Trichiura. In Global Water Pathogen Project; $\quad$ Michigan $\quad$ State $\quad$ University, 2019. https://doi.org/10.14321/waterpathogens.43.

(72) Kotloff, K. L.; Riddle, M. S.; Platts-Mills, J. A.; Pavlinac, P.; Zaidi, A. K. M. Shigellosis. Lancet 2018, 391 (10122), 801-812. https://doi.org/10.1016/S0140-6736(17)33296-8.

(73) Water and Sanitation for the Urban Poor. An Integrated Approach to Peri-Urban Sanitation and Hygiene in Maputo: Working with City Authorities to Improve Services and Practices; Maputo, 2018.

(74) Barreto, M. L.; Genser, B.; Strina, A.; Teixeira, M. G.; Assis, A. M. O.; Rego, R. F.; Teles, C. A.; Prado, M. S.; Matos, S. M. A.; Alcântara-Neves, N. M.; Cairncross, S. Impact of a Citywide Sanitation Program in Northeast Brazil on Intestinal Parasites Infection in Young Children. Environ. Health Perspect. 2010, 118 (11), 1637-1642. https://doi.org/10.1289/ehp.1002058.

(75) Barreto, M. L.; Genser, B.; Strina, A.; Teixeira, M. G.; Assis, A. M. O.; Rego, R. F.; Teles, 
City-Wide Sanitation Programme on Reduction in Rate of Childhood Diarrhoea in

Northeast Brazil: Assessment by Two Cohort Studies. Lancet 2007, 370 (9599), 16221628. https://doi.org/10.1016/S0140-6736(07)61638-9.

(76) Ercumen, A.; Mertens, A.; Arnold, B. F.; Benjamin-chung, J.; Alan, E.; Ahmed, M. A.;

Kabir, M. H.; Khalil, M. R.; Rahman, S.; Parvez, S. M.; Unicomb, L.; Ram, P.; Clasen, T.

F.; Luby, S. P.; Colford, J. M. Characterization of Natural and Affected Environments

(77) Ercumen, A.; Pickering, A.; Kwong, L. H.; Mertens, A.; Arnold, B. F.; Benjamin-, J.;

Ahmed, R.; Parvez, S. M.; Unicomb, L.; Rahman, M.; Ram, P.; Clasen, T. F.; Luby, S. P.;

Colford, J. M. Characterization of Natural and Affected Environments Do Sanitation

Evidence from a Cluster-Randomized Controlled Trial in Rural Bangladesh. Environ. Sci.

(78) Holcomb, D. A.; Knee, J.; Capone, D.; Sumner, T.; Adriano, Z.; Nalá, R.; Cumming, O.; Brown, J.; Stewart, J. R. Bayesian Analysis of Source Tracking Markers to Estimate the Effects of an Urban Sanitation Intervention on Human Fecal Contamination in 
(79) Canter, L.; Knox, R. C. Evaluation of Septic Tank System Effects on Ground Water Quality; Norman, OK, 1984.

(80) Orner, K.; Naughton, C.; Stenstrom, T.-A. Pit Toilets (Latrines). In Water and Sanitation for the 21st Century: Health and Microbiological Aspects of Excreta and Wastewater Management (Global Water Pathogen Project); Mihelcic, J. R., Verbyla, M. E., Eds.;

MI, 2018. https://doi.org/10.14321/waterpathogens.56.

(81) Asaolu, S. O.; Ofoezie, I. E. Ascaris Spp. In Global Water Pathogen Project; Robertson, L., Ed.; Michigan State University, 2019. https://doi.org/10.14321/waterpathogens.41.

(82) Boarato-David, É.; Guimarães, S.; Cacciò, S. Giardia Duodenalis. In Global Water

(83) Verheyen, J.; Timmen-Wego, M.; Laudien, R.; Boussaad, I.; Sen, S.; Koc, A.; Uesbeck, A.; https://doi.org/10.14321/waterpathogens.35.

(84) Ritter, R. L.; Peprah, D.; Null, C.; Moe, C. L.; Armah, G.; Ampofo, J.; Wellington, N.; 
https://doi.org/10.4269/ajtmh.17-0654.

(85) Lamar, F.; Freeman, M. C.; Levy, K. Conceptualizing Chickflows in Maputo, Mozambique: and Hygiene: Mclean, VA, 2019; p 573.

(86) Kwong, L. H.; Ercumen, A.; Pickering, A. J.; Arsenault, J. E.; Islam, M.; Parvez, S. M.; Unicomb, L.; Rahman, M.; Davis, J.; Luby, S. P. Ingestion of Fecal Bacteria along Multiple

Trial of Water, Sanitation, and Hygiene Interventions (WASH Benefits). Environ. Sci.

(88) Liu, J.; Gratz, J.; Amour, C.; Nshama, R.; Walongo, T.; Maro, A.; Mduma, E.; Platts-Mills,

(89) Lappan, R.; Henry, R.; Chown, S. L.; Luby, S. P.; Higginson, E. E.; Bata, L.; Jirapanjawat, 
Cards Enable Monitoring of Diverse Enteric Pathogens across Environmental and Host

Reservoirs. bioRxiv 2020, 2020.10.27.356642. https://doi.org/10.1101/2020.10.27.356642.

(90) Cutler, D.; Miller, G. The Role of Public Health Improvements in Health Advances: The 20th Century United States; Cambridge, MA, 2004. https://doi.org/10.3386/w10511.

(91) Dodane, P. H.; Mbéguéré, M.; Sow, O.; Strande, L. Capital and Operating Costs of Full-

Environ. Sci. Technol. 2012, 46 (7), 3705-3711. https://doi.org/10.1021/es2045234.

(92) Mafuta, C.; Formo, R. K.; Nellemann, C.; Li, F. Green Hills, Blue Cities: An Ecosystems

(93) Cumming, O.; Arnold, B. F.; Ban, R.; Clasen, T.; Esteves Mills, J.; Freeman, M. C.; Gordon, B.; Guiteras, R.; Howard, G.; Hunter, P. R.; Johnston, R. B.; Pickering, A. J.; Prendergast, Programme, GRID-Arendal, 2011.

(94) Un-Habitat. The Challenge of Slums - Global Report on Human Settlements; 2003. Consensus Statement. BMC Med. 2019, 17 (1), 173. https://doi.org/10.1186/s12916-019$1410-x$ 
Development: Making the Links. Ann. N. Y. Acad. Sci. 2014, 1308 (1), 118-128. https://doi.org/10.1111/nyas.12330.

674 (96) Cattaneo, M. D.; Galiani, S.; Gertler, P. J.; Martinez, S.; Titiunik, R. Housing, Health, and Happiness. Am. Econ. J. Econ. Policy 2009, 1 (1), 75-105. https://doi.org/10.1257/pol.1.1.75.

(97) Kolsky, P. Performance-Based Evaluation of Surface Water Drainage for Low Income Communities: A Case Study in Indore, Madhya Pradesh, London School of Hygiene and Tropical Medicine, 1999. https://doi.org/10.13140/2.1.1136.6721. Modeling to Correlate Biosand Filter Performance and Occurrence of Diarrhea in the Village of Enseado Do Aritapera in Para, Brazil. Water Supply 2015, 15 (1), 164-172. https://doi.org/10.2166/ws.2014.101.

(99) Peal, A.; Evans, B.; Blackett, I.; Hawkins, P.; Heymans, C. Fecal Sludge Management: A 